\title{
КРЕАТИВНА БИБЛИОТЕРАПИЈА У ШКОЛСКОЈ БИБЛИОТЕЦИ
}

Сажетак: У раду се разматра појам библиотерапије из угла библиотекара, могућност организовања библиотерапије у школама у односу на циљеве образовања, као и улога школског библиотекара у организацији активности са децом које се заснивају на коришћењу методе креативне библиотерапије. Представљени су примери из праксе библиотекара Основне школе „Свети Сава” у Београду - радионице са темом толеранције уз коришћење збирке прича Риба риби іризе рей, часови пројектне наставе који су засновани на тумачењу дела из школске лектире као што су Мој gека је био йрешња и Орлови рано лешее и сл. Аутор поставља и питање зашто о примени библиотерапије у школама у Србији нема више радова. Један одговор проналази у чињеници да иако школски библиотекари реализују бројне активности са децом, засноване на читању и интерпретацији књижевних дела, које јесу библиотерапија, често не користе тај термин. У закључку аутор позива наставнике и библиотекаре да се подсете свих активности у којима користе методу библиотерапије, да пишу о њима и да их представе јавности.

Кључне речи: креативна библиотерапија, школски библиотекар, школска библиотека, читање, креативност, Основна школа „Свети Сава”.

\section{Увод}

Премда има много радова о библиотерапији који се могу наћи на интернету, мало је оних који долазе из Србије. За разлику од школских библиотекара у Хрватској који у свом раду доста користе библиотерапију и где се много пише о овој теми, приметно је да у Србији има тек неколико радова у којима библиотекари износе своја искуства. Поставља се питање да ли се и како може користити библиотерапија у школи/школској библиотеци и зашто се о томе не пише довољно. 
Овај рад се, након кратког дела у вези са развојем библиотерапије, врстама и корацима у примени, бави библиотерапијом у школама и улогом библиотекара и наставника у организацији активности/радионица са децом које се заснивају на коришћењу методе креативне библиотерапије. Циљ рада је да укаже на повезаност рада школског библиотекара и библиотерапије, да се представе примери из праксе једног библиотекара и позитивни ефекти библиотерапије, као и да се пружи могући одговор на постављено питање.

\section{Појам библиотерапије}

Књижевност је неисцрпан извор знања и спознаја о животу и у одређеним примерима помаже и приликом савладавања животних препрека или на њих упозорава. Сматра се да читање одређене литературе може изменити живот човека. У тим примерима, кад књижевност има неку врсту терапеутске улоге, можемо говорити о библиотерапији.

Ту посебну улогу књижевности препознали су библиотекари у старом веку када на улазу у библиотеке постављају натпис „лечилиште за душу”.

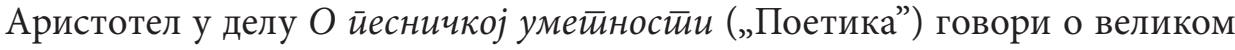
утицају књижевности на читаоце у оквиру дефиниције трагедије и уводи појам катарзе: „Трагедија је, дакле, подражавање озбиљне и завршене радње која има одређену величину, говором који је отмен и посебан за сваку врсту у појединим деловима, лицима која делају а не приповедају; а изазивањем сажаљења и страха врши прочишћење таквих афеката."

Амерички психијатар Семјуел Кротерс (Samuel Crothers) први користи термин „библиотерапија” 1916. у чланку „Литерарна клиника” у часопису The Atlantic Monthly где говори о методи приписивања одређене литературе пацијентима за потребе терапије: „Права улога књижевне критике није да пренесе суд о књизи, него да утврди стање читаоца. Какво је његово стање пре и после читања? Да ли је њему било боље или горе? Из мог угла гледања књига је литерарни лек дат ономе коме је потребан."

Библиотерапија се у 20. веку развија у болницама као део психотерапије, а средином века интересовање за њу показују и библиотекари. Америчко удружење библиотекара усваја 1966. дефиницију библиотерапије:

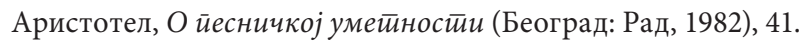

2 Samuel McChord Crothers, "A Literary Clinic", The Atlantic Monthly (1916), https://www.unz. com/print/AtlanticMonthly-1916sep-00291/?View=PDF (преузето 6. 9. 2021). 
„Селекција материјала за читање као помоћног терапијског средства у медицини и психијатрији, такође, водича у решавању личних проблема кроз вођено читање."

Седамдесетих година 20. века библиотекарка Реa Рубин (Rhea Rubin) у тексту „Употреба библиотерапије у одговору на седамдесете” каже да „библиотерапија обухвата различите области које промовишу лични раст кроз разговор о књижевности. Може се користити са нормалним грађанима који желе да нешто више науче о себи, као и са особама које су ментално или социјално неприлагођене и треба да промене своје понашање. Библиотерапија је библиотечки приступ јер се заснива на библиотечкој услузи, као и на принципима психологије и образовања одраслих".

С обзиром на то да библиотерапија има широко поље деловања, у односу на учеснике, циљеве, поставке и оне који је спроводе, разликују се три типа: институционална, клиничка и развојна библиотерапија. Институционална и клиничка библиотерапија спроводе се у болничком окружењу, са групом учесника који имају емоционалне проблеме или проблеме у понашању, воде је психијатри, лекари или библиотекари, а циљ је промена понашања учесника. Развојна библиотерапија користи се у раду са здравом популацијом као превентива у случајевима свакодневних стресних ситуација. Сврха јој је да унапреди нормалан развој и самоактуализацију, или да одржава ментално здравље. Спроводи се, најчешће, у школама и библиотекама са групом деце или одраслих који желе да боље разумеју себе и своје проблеме. Програм осмишљава и води библиотекар или наставник, а то може бити психолог или социјални радник.

Реа Рубин у истом тексту уводи разлику између традиционалне библиотерапије, засноване на читању књига, и креативне у којој учесници стварају књижевна дела: песме, кратке приче, дневничке белешке и сл. Говорећи о трендовима 80-их година 20. века ауторка указује да се као материјал за библиотерапију, осим књиге, може користити и филм.

Може се рећи да је основни принцип на коме се заснива библиотерапија - док читају, људи се идентификују са ликовима књижевног дела и проживљавају њихове емоције, ослобађајући истовремено своје емоције што доводи до промене у начину размишљања о себи и другима и доноси

3 American Library Association, "Bibliotherapy", https://www.ala.org/tools/atoz/bibliotherapy (преузето 6. 9. 2021).

4 Rhea J. Rubin, "Uses of Bibliotherapy in Response to the 1970s", Library trends, 1979, https:// core.ac.uk/download/pdf/4816412.pdf (преузето 6. 9. 2021). 
нове облике понашања. У литератури се наводи да процес библиотерапије има четири фазе процеса: идентификацију, пројекцију, катарзу и увид. ${ }^{5}$

Идентификација је фаза повезивања, поистовећивања са ликом из текста, са искуством или догађајем у причи.

Пројекција је процес при коме читалац себе и своја осећања пројектује у лик са којим се идентификовао и може да преиспитује своје поступке и вреднује их очима лика. Добија увид у различите животне ситуације и њихово разјашњење, а тиме и нова знања и вештине које може да примени у свом животу.

Катарза (појам преузет из Аристотелове Поеиичке) - доживљај емоционалног растерећења и олакшања кроз емоције лика са којим је извршен процес идентификације.

Увид - долажење до увида у личне проблеме, што може бити кључ за њихово решење.

\section{Библиотерапија у школи}

Школа је основно окружење у коме деца успостављају међусобни однос. У њој стичу знања из различитих области и уче да одреде своје циљеве и остваре их, и да разумеју себе и друге. У школи деца треба да се оспособе за рад, даље образовање и самостално учење и за самостално и одговорно доношење одлука које се односе на сопствени развој и будући живот. Циљеви образовања су и да деца развијају позитивне људске вредности, постигну пун интелектуални, емоционални, социјални, морални и физички развој, уважавају различите вредности и да се подстичу на изградњу сопственог система вредности и вредносних ставова који се темеље на начелима различитости и добробити за све, да развијају и негују другарство и пријатељство, усвоје вредности заједничког живота и буду одговорни за своје поступке. ${ }^{6}$

Стога је важно да се деца нађу у ситуацијама и доживе искуства која ће им омогућити да се суоче са проблемима и успешно их реше. Добра сарадња наставника и стручних сарадника доприноси да се брже одреде

5 Dijana Sever, Biblioterapija: primjeri dobre prakse u hrvatskoj i svijetu (Zagreb: Sveučilište u Zagrebu, Filozofski fakultet, 2015), http://darhiv.ffzg.unizg.hr/id/eprint/6085/1/Biblioterapija. pdf (преузето 5. 9. 2021).

6 Министарство просвете, науке и технолошког развоја, „Закон о основама система образовања и васпитања", http://www.mpn.gov.rs/wp-content/uploads/2021/08/Zakon-o-osnovamasistema-obrazovanja-i-vaspitanja.pdf (преузето 6. 9. 2021). 
потребе деце и да им се пружи подршка у личном развоју и стицању сигурности у различитим областима живота. Један од начина на који се може одговорити на дечије потребе је библиотерапија. У школским условима библиотерапија је (развојна, креативна) комбинација читања и промишљања о прочитаном, разговор о књигама да би читалац сагледао одређену ситуацију на другачији начин, решио неки проблем, и/или унапредио лични раст и развој.

Кораци у процесу библиотерапије у школи (школској библиотеци) су:

1. Идентификација специфичних проблема са којима се деца сусрећу;

2. Избор одговарајуће литературе која може да помогне у решавању проблема;

3. Имплементација - након читања текста деца промишљају о понашању ликова и ситуацијама у којима се налазе, пореде их са својим животом (наводе личне примере) и стичу нове увиде (закључке и поуке) који им помажу у проналажењу решења личних проблема;

4. Даље активности које обухватају разговор о делу и приказивање његовог садржаја из различитих углова што подразумева креативност, на пример, кроз препричавање књижевног дела, драмско извођење по улогама, писање приказа, израду дневничких бележака јунака, писање писама, цртање илустрација итд.

Ове активности помажу ђацима да схвате да нису усамљени у суочавању са проблемима, да су људи некад снажни, а некад слаби, и да постоје различити начини решавања дилема и доношења одлука о томе како ће поступити у одређеној ситуацији.

Библиотерапију у школи могу водити библиотекари, наставници, психолози. Као литература користе се песме, приче, бајке, романи, али и филмови и други материјали коју могу бити тема разговора и извор стицања одговарајућих знања и закључака.

\section{Школски библиотекар и библиотерапија у Србији}

Школски библиотекар својим радом доприноси остварењу циљева и задатака рада школе. Учествује у остваривању програма наставе и учења за све предмете, али у свом раду највише сарађује са учитељима и наставницима српског језика и књижевности у подстицању деце на читање и развијању читалачке и медијске писмености и креативности. Од 2018. уводе се у Србији нови наставни програми чија је главна одлика учење усмерено на исходе, пројектна настава и већа примена информационих 
и комуникационих технологија (ИКТ). Оствареност исхода води ка развијању компетенција (кључних, предметних и међупредметних). Уведени су нови наслови у лектири. Програм за седми разред који важи од 2020/2021. ${ }^{7}$ предвиђа да ученици развијају читалачке компетенције, стичу основна знања о медијској писмености и науче како функционално да повезују садржаје предметних области. Један од циљева обраде дела у оквиру лектире је навикавање ученика да своје утиске, ставове и судове о књижевном делу подробније доказују чињеницама из самога текста и тако се оспособљавају за самосталан исказ, истраживачку делатност и заузимање критичких ставова. Такође, треба их подстицати да свет књижевног дела доведу у везу са сопственим искуством, размишљањима и светом у којем живе. (Исти су циљеви и у програмима за пети, шести и осми разред по којима се сада ради.) У свим разредима обрада књижевног дела треба да буде повезана са решавањем проблемских питања подстакнутих текстом и уметничким доживљавањем. На тај начин стимулише се ученичка радозналост, свесна активност и истраживачка делатност.

Библиотерапија као метода рада може се применити управо у остваривању ових задатака.

\section{Креативна библиотерапија у Основној школи „Свети Сава”}

Библиотекар у ОШ „Свети Сава” у Београду као методу користи креативну библиотерапију, било да ради са целим одељењем на часу, и у сарадњи са предметним наставником, или са појединим ученицима у оквиру активности у библиотеци. Реализују се разноврсне активности чији су циљеви: мотивисање ученика за читање и развијање читалачке и медијске писмености, подстицање креативности, развијање социјалних вештина и емоционалне писмености.

\footnotetext{
Министарство просвете, науке и технолошког развоја „Правилник о програму наставе и учења за седми разред основног образовања и васпитања”, Службени іласник Рейублике Србије, Просветини іласник бр. 15 (2018), http://www.pravno-informacioni-sistem.rs/ SlGlasnikPortal/viewdoc?uuid=1cd9f883-ccfe-4a73-8ccd-95bc212169e1 (преузето 5. 9. 2021).
} 


\section{Пројекти за подстицање читања „Оштро Перце” и „Читам, па шта?”}

Библиотекар се приликом одабира књига за библиотерапију води идејом да је најбоље користити наслове из школске лектире, као из пројеката за подстицање читања „Оштро Перце” и „Читам, па шта?” и тако подстаћи децу да читају књиге предвићене школским програмом, али и да учествују у такмичарским пројектима и огледају се у књижевном стваралаштву.

Пројекат „Оштро Перце” повезује програм рада школског библиотекара са школским програмом. Током пројекта ученици читају одређена књижевна дела, одабрана баш зато што су литература за подстицање личног развоја деце или могу бити одговор на проблеме деце у одређеном узрасту (нека су и у програму за Српски језик и књижевност), о њима разговарају са наставницима и библиотекарима, а у даљим активностима приказују њихов садржај из различитих углова - пишу приказе књига и филмова насталих по њима, али и своје приче и бајке, цртају, глуме, израђују трејлере за књиге... Ове активности, засноване на читању и интерпретацији књижевних дела, иако нису назване библиотерапијом, управо су пример примене креативне библиотерапије као методе рада. Тај назив је изостао јер се оне реализују у сарадњи библиотекара и наставника током дужег периода и често као часови тематске и пројектне наставе. Ефекти пројекта, попут успешног тимског рада и сарадње са вршњацима током заједничког рада, затим побољшања социјалних вештина и емоционалне писмености ученика, указују на остваривање циља библиотерапије побољшање психолошког благостања. Коришћењем литературе (прича, романа, филмова рађених на основу књига) ученици се идентификују са ликовима, доживљавају емоционалну катарзу и стичу увид у сопствена животна искуства.

Слично се може рећи и за активности пројекта „Читам, па шта?” јер ученици разговарају о прочитаним књигама са библиотекаром и наставницима и пишу приказе.

8 Пројекат „Оштро Перце”, чије су ауторке Слађана Галушка и Анђелка Танчић, реализује се од 2011. године. Пројекат је представљен на веб-страни Супер учење, https://superucenje. org.rs/perce.

9 „Читам, па шта?” је пројекат Библиотеке града Београда који се реализује од 2015. године. Задатак за ученике је да читају књижевна дела предвиђена програмом такмичења, пишу приказе дела и цртају илустрације. 
Као пример коришћене литературе навешћемо збирку прича Јасминке Петровић Риба риби іризе рей која заузима посебно место у програмима поменутих пројеката. (У пројекту „Оштро Перце” била је од 2011. до 2016, а у програму „Читам, па шта?” од 2015.) Ова књига се у ОШ „Свети Сава” користи сваке године као материјал за радионице са ученицима четвртог разреда које се одржавају поводом обележавања Међународног дана толеранције. Након објашњења значења појма толеранција, кратког представљања књиге и читања једне од пет прича из ње, библиотекарка разговара са ученицима о постојању и поштовању различитости, ђаци наводе примере толерантног и нетолерантног понашања у свом окружењу и промишљају о начину решавања одређених ситуација. Радионица мотивише ученике да прочитају целу књигу и у договору са наставницима библиотекарка организује још неколико часова на којима ученици анализирају збирку прича, дискутују о дешавањима, поступцима јунака и начинима на којима се суочавају са својим проблемима и свакодневним изазовима. Ученици препознају своје проблеме сличне онима које имају јунаци и стичу увид у начине њиховог решавања. Након тога ученици пишу приказе и често се дешава да се разговор о књизи наставља у библиотеци са појединим ученицима или мањом групом деце.

Које су увиде ученици стекли представљамо кроз два примера:

„Читајући ову књигу схватио сам да нико од нас није савршен, али свако има неки таленат који га у нечему чини бољим од осталих. Свако има нешто на себи што му се не допада и мисли да би му живот био песма да му је мањи нос, или да је виши десет центиметара, или да боље игра фудбал, или.... Међутим, треба да мислимо на оне ствари које добро радимо и да не тугујемо због онога што нам се не свиђа."10

„Могу у потпуности да разумем ликове ове књиге јер и сама понекад замуцкујем, али захваљујући својим друговима који на то не обраћају пажњу, не доживљавам то као проблем. Мислим да је ова књига веома поучна и племенита. Писац жели да нам каже да је од тога како изгледамо много важније какве смо особе и јесмо ли добри пријатељи. Свиђа ми се начин на који су дечији проблеми представљени. Нажалост, у реалности ствари не функционишу баш увек овако, али управо зато ова књига може помоћи деци широм света да схвате да нису усамљена у свом проблему. ${ }^{11}$

10 Рад ученика Јована Јовановића, објављен у школском листу Машйарије, број 10, http:// ossvetisavabg.edu.rs/wp-content/uploads/2020/03/mastarije_10_2.pdf

11 Рад ученице Марије Кузмановић објављен у школском листу Машӣарије, број 6, http:// ossvetisavabg.edu.rs/wp-content/uploads/2020/03/mastarije_6.pdf 


\section{Приказ књиге}

Наставнице српског језика и библиотекарка организовале су за ученике петог разреда пројекат „Приказ књиге” у октобру и новембру 2018. Библиотекарка је разговарала са ђацима о књигама и значају читања, а затим су они говорили о својим омиљеним књигама. Добили су задатак и упутство за писање приказа омиљене књиге. У разговору о књигама ученици су препознавали ситуације сличне онима у којима се они налазе и разматрали су начин на који се јунаци суочавају са своји проблемима и колико то може њима као читаоцима помоћи да на једноставнији начин дођу до решења личних проблема, као што су проблем комуникације са члановима породице и друговима или прихватање промена у животу. У другом делу пројекта ученици су писали приказ романа Аїu u Емa. На часовима се дискутовало о роману и темама које се у њему обрађују: однос родитеља и деце, међусобни однос деце у школи, пријатељство итд. Ђаци су говорили о проблемима са којима се Аги суочава и препознавали у свом животу ситуације сличне Агијевим, као и о осећањима среће, туге, љубави која се проживели заједно са јунацима књиге. Роман им се свидео због фрагментарне форме, необичних јунака и њихових доживљаја и због бајковитих и духовитих делова. Ученици су писали приказ романа, цртали илустрације и упоређивали садржај романа и истоименог филма. Закључили су да је читање романа и разговор о њему допринео да боље разумеју и себе и друге, посебно своје родитеље. Препорука је да роман Аїu и Ема треба да читају и деца и одрасли - деца да би знала да сви имају тешкоће и да се оне могу превазићи, одрасли да би знали колико је деци важно да више времена проводе са њима.

Једна девојчица је у приказу књиге написала: „Овај роман је један од најлепших и најнеобичнијих које сам прочитала. Повезала сам га са собом на одређени начин. Када сам почела да тренирам атлетику, нисам имала пријатеља и деца су ми говорила да сам спора. Онда сам упознала Милу, једну од најбољих атлетичарки, која ме је бодрила и била уз мене. Данас смо добре другарице. Упоређујем себе са Агијем, а Милу са Емом и зато ми је ова књига посебно важна и занимљива. Препоручујем је свима, јер и мала деца, као и баке и деке, треба да схвате шта је пријатељство и како да живот посматрамо са лепше стране."12

12 Рад ученице Нефели Папамали објављен у тексту, „Аги и Ема”, http://ossvetisavabg.edu.rs/ wp-content/uploads/2020/04/agi_ema.pdf 


\section{Бајке}

Бајке се обрађују у свим разредима основне школе и део су програма пројекта „Оштро Перце”, те библиотекар организује са наставницима часове на којима ученици интрепретирају бајке (анализа садржаја, тумачење ликова и њихових поступака, уочавање етичког слоја бајке...), а затим се подстичу на стварање својих бајковитих дела. И током школске 2020/2021. организоване су разноврсне активности у вези са бајкама. У априлу 2021. реализовани су часови за ученике трећег и четвртог разреда посвећени бајкама, њеним елементима и порукама, на којима су говорили о омиљеној бајци и о томе шта су научили из ње. То су биле бајке које сви добро познају, из књига или филмова, као што су „Пепељуга”, „Снежана и седам патуљака”, „Лепотица и звер”... Библиотекар је питањима усмеравао децу да разматрају однос добра и зла, разлоге због којих јунак креће у авантуру, каква је улога пријатеља и сл. Посебно је била занимљива дискусија у вези са односом лепотице и звери и потребе да јунак мења своје понашање и постане бољи, што је подстакло децу да говоре о свом понашању и потреби да се у неким сегментима живота промене. Затим су ученици добили упутства за писање бајке и током априла су стварали своје бајковите приче. Могли су да пишу своју бајку, да познату бајку испричају са промењеним временом дешавања (савремена варијанта), или да напишу бајку која ће бити наставак неке познате бајке. Задатак је био и да ту бајку илуструју. За ученике петог и шестог разреда, који су претходних година похађали радионице у вези са бајкама, организовано је такмичење у писању бајки са темом „Пепељуга у 21. веку” и „Снежана у 21. веку”. Ученицима је у писању помагао библиотекар кроз индивидуални рад у библиотеци. Ова активност изнедрила је веома занимљиве бајке у којима су ученици писали о својим проблемима кроз измишљене ликове (бајка чији су ликови воће и поврће као здрава храна, тј. добро, и слаткиши као нездрава храна, тј. зло) или су писали о проблемима младих данас како их они виде уводећи у радњу елементе савременог живота - инстаграм профиле, јутјубере, инфлуенсере, компјутерске игрице...

\section{На крилима књиге}

Часови пројектне наставе „На крилима књиге” реализовани су са ученицима једног одељења шестог разреда од октобра до децембра 2018. године у сарадњи библиотекара и наставника српског језика, технике 
и технологије, грађанског васпитања и веронауке. Једна од метода рада примењена у пројекту била је библиотерапија. Идеја за пројекат је настала на часовима грађанског васпитања. Ученици су уочили један проблем у својој заједници који сматрају важним: мали број активности којима се промовишу књиге и читање за децу њиховог узраста. Решење проблема су видели у томе да они осмисле неку такву активност. Договорено је да ће се бавити романом Moj gека је био йрешюа на нов начин - кроз телевизијску емисију у којој би гости били ликови романа. Активности су започеле обрадом романа на часовима српског језика. Ученици су анализирали роман, разговарали о доживљајима јунака, препознавали поједине ситуације из света књиге у свом животу, откривали поруке и писали приказе. Радња романа послужила је да ученици промишљају о свом односу према члановима породице, као и о томе на који начин би могли да побољшају комуникацију са ближњима. Ученици су затим осмишљавали питања за све јунаке књиге и одговоре који би они дали. На основу интересовања ученика, одређени су учесници емисије, водитељ и шест ликова који ће бити њени гости. Уз помоћ наставнице српског језика и и библиотекарке одабрана су питања и одговори. Питања су се односила на догађаје у роману, али и на оне након самог садржаја. Како се радња романа дешава у граду и селу, ученици су разговарали о разликама једног и другог начина живота и о важности боравка у природи, и осмислили су питања баш у вези са овом темом и тако да говоре о измишљеним дешавањима. Ђаци су телевизијску емисију назвали „На крилима књиге” и осим разговора са ликовима, припремили су рекламе и наградну игру за гледаоце. Неколико девојчица је направило плакат за емисију. На часовима технике и технологије ђаци су у програмима Енвисионар и Гугл Скечап цртали сеоско домаћинство са темом „Мој дека је био трешња”, на часовима информатике и рачунарства разговарали су о изради различитих медијских порука за одређену публику и са одређеном намером. Емисија је изведена два пута током два јавна часа којима су присуствовали ученици шестог и седмог разреда, неколико наставника, педагог и директор школе. Најпре је представљен ток пројекта, а онда су ученици представили роман $M о j$ gека је био йрешюа кроз приказ, интервјуе, рекламе и наградну игру за гледаоце, тј. телевизијску емисију. У вредновању пројекта истакнуто је да је ово добар начин да се будућим читаоцима прикаже једна књига. Посебна вредност емисије је што излази из оквира радње самог романа и што су ученици у делу интервјуа говорили о догађајима којих нема у књизи, али би се могли десити и истакли важне позитивне особине јунака романа. 
Текст о пројекту и дечји радови објављени су на веб-страни школске библиотеке. ${ }^{13}$

\section{Некад и сад}

За ученике шестог разреда библиотекарка и наставница српског језика су у марту и априлу 2019. организовале часове пројектне наставе под називом „Некад и сад”. Циљ је био да ученици унапреде лични развој и боље разумеју своје емоције и понашање, као и понашање других људи, кроз анализу и тумачење романа Орлови рано летее и огледају се у литерарном стваралаштву. Активности су се одвијале од марта до маја 2019. на часовима српског језика и грађанског васпитања и у школској библиотеци, као и на неколико часова технике и технологије. Као метода рада коришћена је библиотерапија - читање и промишљање о прочитаном, сарадничко учење, усмено излагање, писање о осећањима ликова романа, писање дневничких бележака, евалуација. Пројекат је започео причом о важности читања и библиотерапији - о томе да је читање забава и развија машту и емпатију, да пружа нова сазнања и помаже у развијању социјалних вештина, доприноси бољем разумевању себе и других и олакшава суочавање са свакодневним тешкоћама и њихово решавање. Ученици су затим читали роман Орлови рано летее и разговарали са наставницом о теми и развоју радње, јунацима, проблемима са којима се они суочавају и њиховим осећањима. У другом делу пројекта ђаци су говорили о животу деце некад и сад кроз сагледавање животних прилика ликова из романа и упоређивање са свакодневним дешавањима у свом животу. Задатак је био да препричају поједине делове романа, да пишу о осећањима ликова у тим ситуацијама и да на основу самог дела напишу дневничке белешке јунака. Затим су писали своје дневничке белешке током једне седмице. На наредним часовима ђаци су читали своје радове и разговарали о животу деце некад и сад. Било је мишљења да је некад деци било занимљивије, посебно у селу - сваки дан је доносио нову авантуру, имали су већу слободу и играли су се у природи. Други су пак рекли да је данас занимљивије, јер имају већи избор активности и да не могу да замисле живот без савремене технологије. Причали су о својим свакодневним активностима и разматрали како оне могу бити авантуре ако се посматрају из другог угла. Текстове су припремили у електронској форми на часовима технике и технологије.

13 ОШ „Свети Сава” Београд, „Наставни материјал”, http://ossvetisavabg.edu.rs/nastavnimaterijal/ 
Закључили су да је читање романа и разговор о њему допринео да схвате да њихови проблеми, за које мисле да су велики, у ствари уопште и нису проблеми кад се упореде са проблемима јунака романа. Неколико часова у оквиру пројекта посвећено је разговору о срећи: о томе да ли су деца срећна, шта их може усрећити и који су разлози да не буду срећна. Затим су ученици за писмени из српског језика добили тему „Ја сам срећан”. Ови разговори су им помогли да почну да преиспитују своја уверења о томе шта значи бити срећан, колико познају и воле себе и колико слика о њима самима зависи од туђег мишљења. На почетку разговора већина је рекла да нису срећни и да им за срећу треба да буду лепши, мршавији, виши, да се свиђају другима и сл. Током часова су, ипак, дошли и до другачијих сазнања - срећни су јер имају добре животне услове, заштићени су, имају другове, добри су ђаци, јединствени су, паметни... На крају пројекта ученици су рекли да су им часови били занимљиви и да су сазнали неке нове ствари о себи кроз разговоре о књижевним јунацима. Текст о пројекту и дечји радови објављени су на веб-страни школске библиотеке. ${ }^{14}$

\section{Закључак}

Креативна библиотерапија (промишљање о књигама и стваралаштво инспирисано њима) део је активности школског библиотекара. Одговор на питање са почетка рада могао би гласити да се у српским школама много више користи метода развојне и креативне библиотерапије него што то показују извештаји о раду или стручни радови. Један од доказа је чињеница да је у десет сезона пројекта „Оштро Перце” учествовало 40 школа из Србије и стотину библиотекара и наставника. Иако су сви користили библиотерапију у раду, сам термин није коришћен. Слично је и са другим пројектима за подстицање читања и развијање креативности код ученика који се реализују у Србији, а чији аутори користе термине у складу са документима у области просвете где се истичу методе активног учења, развијање међупредметних компетенција, стваралаштво и сл. Овај рад је стога и позив школским библиотекарима и наставницима да се подсете свих активности у којима користе методу библиотерапије, да пишу о њима и да их представе јавности.

14 ОШ „Свети Сава”, Београд, „Наставни материјал”, http://ossvetisavabg.edu.rs/nastavni-materijal/ 


\section{Literatura:}

1. American Library Association, "Bibliotherapy", https://www.ala.org/tools/atoz/ bibliotherapy (preuzeto 6. 9. 2021).

2. Aristotel. O pesničkoj umetnosti. Beograd: Rad, 1982. (na ćirilici)

3. Crothers, Samuel McChord. "A Literary Clinic". The Atlantic Monthly (1916), https://www.unz.com/print/AtlanticMonthly-1916sep-00291/?View=PDF (preuzeto 6. 9. 2021).

4. Ministarstvo prosvete, nauke i tehnološkog razvoja. „Pravilnik o programu nastave i učenja za sedmi razred osnovnog obrazovanja i vaspitanja", Службени іласник Рейублике Србије, Просвеитни іласник број 15 (2018), http://www.pravno-informacioni-sistem.rs/SlGlasnikPortal/viewdoc? uuid=1cd9f883-ccfe-4a73-8ccd-95bc212169e1 (preuzeto 5. 9. 2021).

5. Ministarstvo prosvete, nauke i tehnološkog razvoja. „Zakon o osnovama sistema obrazovanja i vaspitanja", http://www.mpn.gov.rs/wp-content/uploads/2021/08/ Zakon-o-osnovama-sistema-obrazovanja-i-vaspitanja.pdf (preuzeto 6. 9. 2021).

6. Rubin, Rhea J. „Uses of Bibliotherapy in Response to the 1970s”, Library trends (1979), https://core.ac.uk/download/pdf/4816412.pdf (preuzeto 6. 9. 2021).

7. Sever, Dijana. „Biblioterapija: primjeri dobre prakse u hrvatskoj i svijetu”. Zagreb: Sveučilište u Zagrebu, Filozofski fakultet, 2015, http://darhiv.ffzg.unizg.hr/ $\mathrm{id} /$ eprint/6085/1/Biblioterapija.pdf (preuzeto 5. 9. 2021). 


\section{Slađana Galuška}

Primary School "Sveti Sava”, Belgrade

sladjanagaluska@gmail.com

\section{CREATIVE BIBLIOTHERAPY IN A SCHOOL LIBRARY}

Summary: The paper considers the term bibliotherapy from the librarian's point of view, possibilities for using bibliotherapy in the classroom concerning education aims and the school librarian's role in activities with children based on creative bibliotherapy. Activities of the school librarian in Sveti Sava Primary School in Belgrade are presented through tolerance workshop with a storybook Riba ribi grize rep and projects based on two novels - Moj deka je bio trešnja (My Grandfather Was a Cherry Tree) and Orlovi rano lete (Eagles Fly Early). The author wonders why there are only a few papers about using bibliotherapy in Serbian schools. One of the possible reasons lies in the fact that school librarians realize numerous activities with children based on reading and literary interpretation, but they are not recognized as bibliotherapy.

In conclusion, teachers and school librarians should remind themselves of all bibliotherapy activities they have done, write about them and present them in public.

Keywords: creative bibliotherapy, school librarian, school library, reading, creativity, Sveti Sava Primary School. 